\title{
Evaluation of 3-week Repeated Dose Oral Toxicity on Amomum tsao-ko Extract in Balb/c Mice
}

\author{
Ju-Hyeong Park $\cdot$ Young-Rak Cho $\cdot$ Hye-Jin Ko $\cdot$ Wonsik Jeong $\cdot$ Eun-Kyung \\ Ahn $\cdot$ Junho Oh $\cdot$ Joa Sub Oh*
}

\section{Balb/c 마우스에서 초과 추출물의 3주간 반복 경구투여 독성평가}

박주형 · 조영락 · 고혜진 · 정 원식 · 안은경 · 오준호 · 오좌섭*

\begin{abstract}
In the present study, we investigated the oral toxicity of Amomum tsao-ko Crevost et Lemaire, (Zingiberaceae) extract in Balb/c mice (BALB, $\mathrm{n}=60$ ) for 3 weeks. Balb/c mice (10 mice/ group, 6 group, $20 \pm 2 \mathrm{~g}, 6$ weeks) were orally administered for 21 days, with dosage of $250,500,1000,2000 \mathrm{mg} / \mathrm{kg} /$ day. Ethanol
\end{abstract}

\section{J.-H. Park}

College of Pharmacy, Dankook University, 119 Dandae-ro, Cheonan 330714 , Republic of Korea

W. Jeong

College of Pharmacy, Dankook University, 119 Dandae-ro, Cheonan 330714 , Republic of Korea

Natural Products Research Institute, Gyeonggi Institute of Science \& Technology Promotion, Suwon, 147 Gwanggyo-ro, Gyeonggi-Do 443270 , Republic of Korea

Y.-R. Cho $\cdot$ H.-J. Ko $\cdot$ E.-K. Ahn

Natural Products Research Institute, Gyeonggi Institute of Science \& Technology Promotion, Suwon, 147 Gwanggyo-ro, Gyeonggi-Do 443270 , Republic of Korea

J. Oh

Department of Biology, Duke University, USA

J.S. Oh

College of Pharmacy, Dankook University, 119 Dandae-ro, Cheonan 330714, Republic of Korea

Natural Products Research Institute, Gyeonggi Institute of Science \& Technology Promotion, Suwon, 147 Gwanggyo-ro, Gyeonggi-Do 443270, Republic of Korea

*Corresponding author (J. S. Oh: jsoh@dankook.ac.kr)

This is an Open Access article distributed under the terms of the Creative Commons Attribution Non-Commercial License (http://creativecommons. org/licenses/by-nc/3.0/) which permits unrestricted non-commercial use, distribution, and reproduction in any medium, provided the original work is properly cited. extract of A. tsao-ko did not affect any significant change of mortality, clinical signs, organs and body weights. Also, there were not significantly difference from the naive group (control) in hematological and serum biochemical examination. Consequently, these findings indicate that 3-week treatment with the ethanol extract of A. tsao-ko was not any toxic effects in Balb/c mice and the no-observed adverse effect level (NOAEL) for oral toxicity was determined to be $2000 \mathrm{mg} / \mathrm{kg} /$ day under our experimental conditions.

Keywords 3-week repeated-dose oral toxicity - Amomum tsao$k o \cdot$ Balb/c mouse $\cdot$ hematology $\cdot$ serum biochemical examination

\section{서 론}

급속한 산업의 발달과 그에 따른 경제성장으로 생활수준과 삶 의 질이 향상되었으나 환경오염에 따른 개인의 삶의 환경은 직 간접적으로 위협받고 있다. 이에 현대인들의 건강과 웰빙문화에 대한 관심은 점점 고조되고 있고, 점점 심화되는 고령화에 따 라 건강유지나 만성 복합질환의 치료와 개선에 도움을 줄 것으 로 기대되는 천연물 의약품에 대한 관심도 집중되고 있다(Lee 등, 2003; Na 등, 2013). 천연물을 기원으로 하는 생약들은 우 리나라를 비롯한 동양문화권에서는 삶의 유지를 위해 전통적으 로 질병치료나 보약의 처방으로 사용되어 왔으나, 최근에는 기 능성 식품, 기능성 화장품, 건강보조식품 등의 원료로 다양하게 개발되고 있다. 그러나 안전성에 대해서는 한방에서 오랜 기간 사용되어 왔다는 사실로 널리 사용되어 올 뿐 체계적인 제조, 관리, 사용상의 주의사항과 같은 과학적인 근거가 미확보된 상 태로 생약제제에 대한 안전성과 품질관리에 대한 검토가 시급 
한 실정이다(Hwang 등, 2013; Um 등, 2013; Yoon 등 2014). 생강과(Zingiberaceae)에 속하는 초과(Amomum tsao-ko Crevost et Lemaire)는 중국음식과 중국전통의술에서 향신료로 사용하였 다. 맵고 따듯한 성질의 초과는 전통적으로 복통, 메스꺼움, 구 토, 설사, 위장병에 사용하는 것으로 알려져 있다(Yu 등, 2010). Moon 등(2005)은 초과 메탄올 추출물에서 Human non-small cell lung cancer, A549와 Melanoma, SK-Mel-2 cell line에 대한 세포독성 활성을 보고하였으며, Yang 등(2010)은 초과로 부터 얻은 essential oil의 HepG2, Hela, Bel-7402, SGC-7901 및 PC-3 cell line에서 세포독성 및 apoptosis 유도와 항산화 활 성을 보고하였다. 또한 초과 메탄올 추출물에서 $\mathrm{NO}$ 생성의 감 소와 LPS로부터 자극된 RAW264.7 macrophages에서 항염증 활성이 보고되었으며(Li 등, 2014), Trycophyton mentagrophytes 에 대한 항 진균 활성이 보고되었다(Moon 등, 2004).

이와 같은 초과의 다양한 효능이 밝혀짐에 따라 앞으로 초과 를 이용한 많은 건강 기능성 식품 및 의약품들이 개발될 것으 로 예상된다. 하지만 아직까지 초과의 장기간 복용으로 인한 독 성이나 부작용에 대한 보고는 찾아보기 어려우며, 과학적인 시 험법을 이용한 독성평가는 전무한 실정이다. 따라서 본 연구에 서는 식품의약품안전처 고시 제2014-6호(2014년 1월 29일) '의 약품등의 독성시험기준' 의거에 맞는 독성시험법에 따라 $\mathrm{Balb/c}$ mouse를 이용하여 초과 추출물의 3 주간 반복 경구투여 후 혈 액학적, 혈액생화학 검사를 실시하여 안전성을 확인하고자 하였다.

\section{재료 및 방법}

시험방법. 식품의약품안전처 고시 제2014-6호(2014년 1월 29일) '의약품등의 독성시험기준'에 의거하였다.

초과 에탄올 추출물 제조. 초과(Amomum tsao-ko)는 2011년 6 월 서울 소재지 경동시장에서 구입하였으며, 단국대학교(Korea) 오좌섭 교수가 동정한 후 사용하였다. 표본은 (재)경기과학기술 진흥원 천연물신약연구소 천연물연구팀(표본번호: G47, Korea) 에 보관중이다. 초과 추출물의 제조로는 건조된 초과 $9.5 \mathrm{~kg}$ 에 $80 \%$ 에탄올 $(95 \%$ 발효주정, SAMCHUN CHEMICAL (Korea)) $30 \mathrm{~L}$ 를 가하여 상온에서 3 일씩 2회 반복추출 후 여과지로 여과 하였다. 얻어진 $80 \%$ 에탄올 여액을 감압 농축 후 동결 건조하 여 초과 추출물을 얻었다.

시험물질의 조제 및 투여. 시험물질은 시험물질 보관 냉장고에 보관하며 순도에 대한 보정 없이 중량 그대로를 조제에 사용하 였다. 부형제는 중외제약의 생리식염수를 사용하였다. 정량의 실 험물질을 전자저울로 칭량하여 부형제를 넣어 교반기로 교반하 여 규정 농도로 조제하였다. 초과 추출물을 균일하게 용해시켜 경구투여 한계용량으로 가장 많이 사용되는 고용량 $(2000 \mathrm{mg} / \mathrm{kg})$ 을 조제한 후, 이 용액을 2 배수 간격으로 단계별 희석을 통해 나머지 시험군 $(1000,500$, 및 $250 \mathrm{mg} / \mathrm{kg})$ 을 설정하였다(Chung 등, 2011). 투여당일 오전에 조제 후 바로 투여하기 때문에 안 정성 시험은 수행하지 않았다. 존데를 이용하여 경구투여 하였 고, 초과 추출물은 투여 기간 동안 냉장보관 하였으며, 투여횟 수 및 기간은 1회/일, 6일/주, 3주간 오후에 진행하였다(Jung 등, 2011; Yoo와 Jung, 2012). 모든 동물실험은 (재)경기과학기술진 흥원 동물실험윤리위원회의 동물실험표준작업지침서(Standard Operation Procedures, SOP)에 따라 수행하였다(승인번호: 201412-0012).
실험동물. 본 독성실험에 사용한 실험동물은 오리엔트바이오 (Korea)에서 6주령의 특정병원균 부재(Specific Pathogen Free, $\mathrm{SPF}$ ) Balb/c mice (BALB/cAnNCrljOri)수컷 62마리를 입수하 였다. 입수 당일 미생물 검사성적서와 동물의 외관을 검사하였 고, 순화과정 후에 $20 \pm 2 \mathrm{~g}$ 의 건강한 마우스 60 마리를 군당 10 마리씩 실험에 사용하였으며, 군 분리는 투여 전일에 체중을 측 정하고 Z Z배열법에 따라 군간 체중을 고르게 분리하였다. 본 시 험에 사용하는 마우스는 독성시험에 널리 사용되고 있으며 풍 부한 시험 기초 자료가 축적되어 있어, 이를 시험결과의 해석 및 평가에 활용할 수 있기 때문에 선택하였다.

사육환경. 온도는 $22.2 \pm 2^{\circ} \mathrm{C}$, 상대습도 $55 \pm 5 \% \mathrm{RH}$, 조명시간은 명암시간은 형광등조명 12시간주기(07:00 점등 19:00 소등) 및 조도 $250 \mathrm{Lux}$, 온·습도는 주기적으로 측정, 환기횟수 $10 ~ 15$ 회/h, 암모니아 농도 $5 \mathrm{ppm}$ 이하, 소음 $50 \mathrm{~dB}$ 이하로 설정된 (재)경 기과학기술진흥원 천연물신약연구소 동물실험실 SPF 사육구역 에서 사육하였다. 실험에 사용한 동물은 폴리설폰제 사육상자 $(250 \mathrm{~W} \times 350 \mathrm{~L} \times 180 \mathrm{H}(\mathrm{mm}))$ 에 3 마리 이하로 수용하였고, 사육 상자의 환경은 정기적으로 점검하여 일정한 표준차를 유지하였다. 사료 및 물의 급여방법. 사료(Teklad Certified Irradiated Global $18 \%$ protin Rodent Diet, Harlan Co. Ltd, USA)는 두열바이 오텍(Korea)으로부터 공급받아 급이기에 넣고 자율급이하였다. 음수는 수돗물을 폴리설폰제 물병에 넣고 자율급이하였다. 오염 물질의 검사는 사료 생산자로부터 공급된 자료 및 국가공인 검 사기관에서 검사한 자료를 참고하였다.

일반증상관찰 및 체중측정. 모든 동물에 대하여 매일 1 회 일반 증상을 관찰하였으며, 투여 당일에는 투여 후 6시간 까지 매 시 간마다 관찰하였다. 모든 동물의 체중을 입수 시, 군 분리 시, 투여 전, 투여개시일, 투여 후 주 2회, 부검 전일에 측정하였다. 부검일은 절식을 실시하였으므로, 체중평가에서 제외하고 부검 전일 체중을 최종무게로 평가하였다(Lee 등, 2003).

부검. 부검 전 절식한 부검 동물에 대하여 부검 당일에 동물전 용 마취제(Zoletil 50, (주)버박코리아, Korea)로 복강 투여 (intraperitoneal, IP)로 마취 후, 개복하여 복대동맥에서 혈액학 적 검사 및 혈액생화학적 검사를 위해 채혈한 후 치사하여 장 기에 대한 육안적인 부검소견을 관찰하였다(Roh 등, 2014).

혈액학적 검사. 모든 동물에 대하여 부검 후 혈액을 채취하여 항응고제인 Ethylenediaminetetraacetic acid 가 들어있는 채혈튜 브(BD Caribe, Ltd, $\mathrm{USA})$ 에 넣어 $\mathrm{CBC}$ 분석기(BECKMAN COULTER AcTdiff ${ }^{\mathrm{TM}}$, USA)로 WBC (White blood cell count), RBC (Red blood cell count), HGB (hemoglobin concentration), HCT (Hematocrit), MCV (Mean corpuscular hemoglobin), $\mathrm{MCH}$ (Mean corpuscular hemoglobin), MCHC (Mean corpuscular hemoglobin concentration), PLT (Platelet) 을 검사하였다(Kim 등, 2014).

혈액생화학적 검사. 혈액학적 검사를 실시한 동물의 혈액을 원심 분리기(Centrifuge 5415R, EPPENDORF, Germany) 3,000 rpm, 15 분간 원심 분리하여 얻은 혈장을 이용하여 자동생화학분석기 (7021, Hitachi, Japan)로 GLU (Glucose), CREA (Creatinine), TP (Total protein), ALB (Albumin), GOT (Glutamate oxaloacetate transaminase), GPT (Glutamate pyruvate transaminase), T-BIL (Total bilirubin), D-BIL (Direct bilirubin), T-CHO (Total cholesterol), TG (Triglyceride), HDL (High density lipoprotein), BUN (Blood urea nitrogen), LDL (Low density lipoprotein), IP (Inorganic phosphorous), LDH (Lactate dehydrogenase)를 
측정하였다(Lee 등, 2014).

장기중량. 모든 동물에 대하여 채혈 후 심장(heart), 신장 (kidney), 간(liver), 폐(lung), 비장(spleen)을 적출하고 각각의 전 자저울을 이용하여 중량을 측정하였다. 양측성 장기에 속하는 신장은 왼쪽 장기만 적출하여 측정하였다.

통계 처리. 본 시험에서 얻은 결과는 평균 \pm 표준편차로 나타내 었으며, one-way analysis of variance (ANOVA) 분석을 실시 한 후, 유의성이 인정될 경우 Dunnett's t-test를 실행하여 대조 군과 각 시험군 간의 통계학적 유의성을 검정하였다 $(p<0.05)$.

\section{결과 및 고찰}

일반증상. 3 주간의 초과 추출물 투여기간 동안 전 시험군에서 유의할 만한 이상 증상은 관찰되지 않았고, 대조군을 포함한 모 든 시험군에서 초과 추출물 투여기간 동안 사망동물은 없었다. 일반증상 관찰 결과 시험물질의 영향으로 보이는 이상증상은 관 찰되지 않았다.

체중변화. 3 주간의 초과 추출물 투여기간 동안 수컷 $\mathrm{Balb} / \mathrm{c}$ mouse의 체중변화에 있어서 초과 추출물 투여로 인한 유의성 있는 변화는 관찰되지 않았다(Fig. 1). 체중측정결과, 정상군과 유사하게 모든 시험동물에서 정상적인 체중증가가 관찰되었다. 혈액학적 검사. 수컷 $\mathrm{Balb} / \mathrm{c}$ mouse에 초과 추출물을 각각 3 주간 반복 투여한 후, 부검을 통하여 복대동맥으로부터 채혈한 혈액 을 이용하여 $\mathrm{WBC}$ (백혈구), RBC (적혈구), $\mathrm{HGB}$ (헤모글로빈), $\mathrm{HCT}$ (헤마토크릿), $\mathrm{MCV}$ (평균혈구 용적), $\mathrm{MCH}$ (평균적혈구 색 소량), $\mathrm{MCHC}$ (평균적혈구 혈색소 농도), PLT (혈소판)을 분석 하였다. 대조군과 초과 추출물을 농도별로 투여한 모든 군의 평 균값과 표준편차의 결과를 비교한 결과 대조군과 초과 추출물 투여군 간의 통계적인 유의성을 관찰 할 수 없었다(Table 1).

혈액생화학적검사. 초과 추출물을 각각의 농도별로 3 주간 반복 경구투여한 후, 복대동맥으로부터 채혈한 혈액의 혈청을 이용하 여 간기능 $(\mathrm{GOT}, \mathrm{GPT}, \mathrm{LDH}, \mathrm{ALB}, \mathrm{TP}, \mathrm{T}-\mathrm{BIL}, \mathrm{D}-\mathrm{BIL})$, 신장 기능(BUN, $\mathrm{CRE})$, 지질영양 관련( $\mathrm{TCHO}, \mathrm{TG})$, 전해질(I.P) 관 련 지표들을 분석한 결과, 대부분의 지표들에서 대조군과 초과 추출물 투여군 간의 통계적인 유의성을 관찰 할 수 없었다(Table 2). 이 가운데 GLU 그리고 I.P가 초과 추출물 투여농도에 따라 유의성 있게 증가하는 경향을 보였고, 초과 추출물 $2000 \mathrm{mg} / \mathrm{kg}$ 에서 $\mathrm{LDH}$ 가 감소하는 경향을 보였으나 이러한 증가와 감소는 정상 범위 내에서의 변화로써 초과 추출물의 투여에 의한 영향 은 아닌 것으로 판단된다.

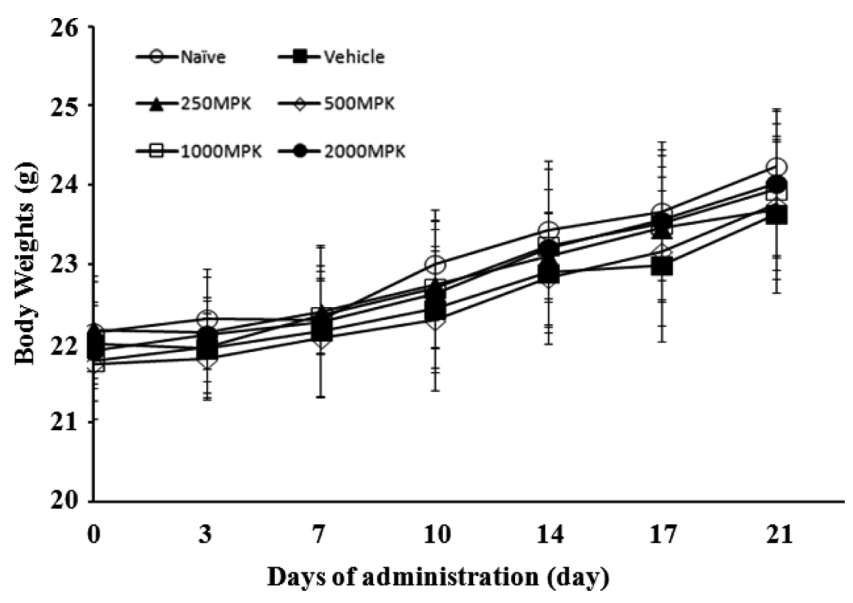

Fig. 1 Change in body weights of male Balb/c mouse during oral administration treated with $A$. tsao-ko extract for 21 days. $\bigcirc$, naive; vehicle (PBS) control; $\boldsymbol{\Delta}$, A. tsao-ko $250 \mathrm{mg} / \mathrm{kg} ; \diamond$, A. tsao-ko $500 \mathrm{mg} /$ $\mathrm{kg} ; \square$, A. tsao-ko $1000 \mathrm{mg} / \mathrm{kg}$; , A. tsao-ko $2000 \mathrm{mg} / \mathrm{kg}$.

장기 중량 측정. 실험종료 시 모든 생존 동물에 대한 부검을 통 해 간, 폐, 심장, 신장, 비장의 중량을 측정한 결과, 초과 추출 물 투여 농도에 의존적인 이상 변화는 관찰되지 않았다(Table 3). 초과 추출물 투여농도에 따라 장기의 중량이 증가하는 경향 을 보였으나, 이는 정상범위 내에서의 변화로써 대조군과 초과 추출물 투여군 간의 통계적인 유의성을 관찰 할 수 없었다.

부검 및 육안검사 소견. 부검 결과, 3주간의 부형제 투여 대조 군과 초과 추출물 투여군 모두에서 육안적으로 관찰되는 병변 이 발견되지 않았다.

최대 무독성 용량. 3 주간 초과 추출물을 $250,500,1000$, 그리 고 $2000 \mathrm{mg} / \mathrm{kg}$ 의 용량으로 경구투여한 결과 혈액 생화학 검사 와 장기무게에서 초과 추출물 투여에 의한 변화가 관찰 되었지 만, 이는 모두 정상범위를 벗어나지 않는 범위 내에서의 증가 현상으로 초과 추출물에 의한 영향은 아닌 것으로 판단된다. 따 라서 최대무독성용량은 최고 투여량인 $2000 \mathrm{mg} / \mathrm{kg}$ 이상으로 판 정함이 타당하다고 여겨진다.

본 연구는 식품의약품안전처 고시 ‘의약품등의 독성시험기준' 에 맞는 독성시험법에 따라 초과 추출물의 3 주 반복 경구투여 독성시험으로 진행되었으며, 결과적으로 초과가 비교적 안전한 물질인 것을 확인 할 수 있었다. 일부의 동물에서 혈액생화학 적 지표 및 장기 중량의 변화를 초래하였지만, 이는 모두 정상

Table 1 Hematological analysis of male Balb/c mouse treated with A. tsao-ko extract for 21 days

\begin{tabular}{ccccccccc}
\hline Parameters & WBC $\left(10^{3} / \mu \mathrm{L}\right)$ & $\mathrm{RBC}\left(10^{6} / \mu \mathrm{L}\right)$ & HGB $(\mathrm{g} / \mathrm{dL})$ & HCT $(\%)$ & MCV $(\mathrm{fL})$ & $\mathrm{MCH}(\mathrm{pg})$ & $\mathrm{MCHC}(\mathrm{g} / \mathrm{dL})$ & PLT $\left(10^{3} / \mu \mathrm{L}\right)$ \\
\hline Naïve & $5.66 \pm 1.14$ & $9.55 \pm 0.26$ & $15.27 \pm 0.43$ & $48.87 \pm 1.04$ & $51.16 \pm 0.64$ & $15.99 \pm 0.28$ & $31.26 \pm 0.40$ & $1062.91 \pm 61.19$ \\
Vehicle & $5.21 \pm 1.34$ & $9.88 \pm 0.35$ & $15.54 \pm 0.69$ & $50.15 \pm 2.06$ & $50.75 \pm 0.64$ & $15.73 \pm 0.30$ & $30.97 \pm 0.51$ & $1045.60 \pm 61.69$ \\
$250 \mathrm{MPK}$ & $5.58 \pm 1.62$ & $9.81 \pm 0.52$ & $15.50 \pm 0.76$ & $49.74 \pm 2.66$ & $50.66 \pm 0.82$ & $15.80 \pm 0.27$ & $31.19 \pm 0.27$ & $1051.60 \pm 59.55$ \\
$500 \mathrm{MPK}$ & $4.71 \pm 0.77$ & $9.80 \pm 0.55$ & $15.56 \pm 0.79$ & $49.97 \pm 2.49$ & $50.97 \pm 0.53$ & $15.90 \pm 0.23$ & $31.21 \pm 0.34$ & $957.1 \pm 159.00$ \\
$1000 \mathrm{MPK}$ & $4.77 \pm 1.28$ & $9.74 \pm 0.52$ & $15.39 \pm 0.71$ & $49.39 \pm 2.49$ & $50.69 \pm 1.08$ & $15.79 \pm 0.33$ & $31.15 \pm 0.33$ & $1013.40 \pm 80.06$ \\
$2000 \mathrm{MPK}$ & $5.07 \pm 1.08$ & $9.81 \pm 0.31$ & $15.54 \pm 0.50$ & $50.11 \pm 1.66$ & $51.10 \pm 0.51$ & $15.86 \pm 0.25$ & $31.00 \pm 0.41$ & $1065.90 \pm 45.67$ \\
\hline
\end{tabular}

Values are expressed as mean \pm standard deviation (SD) for Balb/c.

WBC: white blood cell, RBC: red blood cell, HGB: hemoglobin, HCT: hematocrit, MCV: mean cell volume, $\mathrm{MCH}$ : mean cell hemoglobin, MCHC: mean cell hemoglobin concentration, PLT: platelet.

$(p<0.05)$ 
Table 2 Serum biochemical analysis of male Balb/c mouse treated with A. tsao-ko extract for 21 days. Values are presented as the means \pm standard deviations

\begin{tabular}{|c|c|c|c|c|c|c|c|c|}
\hline Group/Item & GOT & GPT & LDH & T.CHO & HDL & LDL & TG & GLU \\
\hline Unit & $\mathrm{U} / \mathrm{L}$ & $\mathrm{U} / \mathrm{L}$ & $\mathrm{U} / \mathrm{L}$ & $\mathrm{mg} / \mathrm{dL}$ & $\mathrm{mg} / \mathrm{dL}$ & $\mathrm{mg} / \mathrm{dL}$ & $\mathrm{mg} / \mathrm{dL}$ & $\mathrm{mg} / \mathrm{dL}$ \\
\hline Naïve & $36.37 \pm 5.11$ & $19.30 \pm 6.99$ & $159.29 \pm 48.43$ & $140.71 \pm 10.47$ & $77.08 \pm 20.46$ & $4.70 \pm 0.97$ & $128.23 \pm 34.67$ & $211.36 \pm 67.50$ \\
\hline Vehicle & $38.44 \pm 5.66$ & $18.44 \pm 4.06$ & $140.49 \pm 88.41$ & $140.02 \pm 7.41$ & $81.33 \pm 8.49$ & $4.88 \pm 1.23$ & $109.29 \pm 25.01$ & $237.84 \pm 63.19^{* *}$ \\
\hline $250 \mathrm{MPK}$ & $38.44 \pm 5.46$ & $17.97 \pm 5.23$ & $137.49 \pm 40.50$ & $143.39 \pm 9.22$ & $81.33 \pm 8.90$ & $5.43 \pm 1.42$ & $130.34 \pm 37.22$ & $287.36 \pm 87.07^{*}$ \\
\hline $500 \mathrm{MPK}$ & $36.37 \pm 4.92$ & $16.72 \pm 3.91$ & $150.82 \pm 41.70$ & $147.74 \pm 14.79$ & $84.12 \pm 12.11$ & $5.66 \pm 0.98$ & $116.58 \pm 23.88$ & $307.87 \pm 53.84^{* *}$ \\
\hline 1000MPK & $46.37 \pm 25.89$ & $20.62 \pm 4.18$ & $149.07 \pm 60.11$ & $150.64 \pm 9.68$ & $83.83 \pm 8.25$ & $4.86 \pm 1.66$ & $121.23 \pm 33.91$ & $298.51 \pm 50.19^{* *}$ \\
\hline 2000MPK & $37.16 \pm 6.60$ & $20.40 \pm 4.76$ & $127.20 \pm 28.63^{*}$ & $150.64 \pm 16.38$ & $85.63 \pm 10.03$ & $5.66 \pm 1.94$ & $114.07 \pm 33.06$ & $330.95 \pm 89.96^{* *}$ \\
\hline Group/Item & TP & \multicolumn{2}{|c|}{ ALB } & T-BIL & D-BIL & BUN & IP & CREA \\
\hline Unit & $\mathrm{g} / \mathrm{dL}$ & \multicolumn{2}{|c|}{$\mathrm{g} / \mathrm{dL}$} & $\mathrm{mg} / \mathrm{dL}$ & $\mathrm{mg} / \mathrm{dL}$ & $\mathrm{mg} / \mathrm{dL}$ & $\mathrm{mg} / \mathrm{dL}$ & $\mathrm{mg} / \mathrm{dL}$ \\
\hline Naïve & $4.85 \pm 0.45$ & \multicolumn{2}{|c|}{$1.60 \pm 0.24$} & $0.07 \pm 0.02$ & $0.09 \pm 0.01$ & $23.75 \pm 2.48$ & $10.22 \pm 0.83$ & $0.60 \pm 0.09$ \\
\hline Vehicle & $4.89 \pm 0.28$ & \multicolumn{2}{|c|}{$1.65 \pm 0.12$} & $0.08 \pm 0.03$ & $0.09 \pm 0.02$ & $20.75 \pm 2.10$ & $10.21 \pm 1.57$ & $0.62 \pm 0.10$ \\
\hline $250 \mathrm{MPK}$ & $4.73 \pm 0.34$ & \multicolumn{2}{|c|}{$1.61 \pm 0.13$} & $0.07 \pm 0.02$ & $0.08 \pm 0.01$ & $24.42 \pm 3.02$ & $11.33 \pm 1.08$ & $0.54 \pm 0.21$ \\
\hline $500 \mathrm{MPK}$ & $4.80 \pm 0.36$ & \multicolumn{2}{|c|}{$1.64 \pm 0.14$} & $0.07 \pm 0.02$ & $0.08 \pm 0.02$ & $25.33 \pm 5.72$ & $12.41 \pm 1.42^{* *}$ & $0.61 \pm 0.07$ \\
\hline 1000MPK & $4.73 \pm 0.28$ & \multicolumn{2}{|c|}{$1.60 \pm 0.14$} & $0.07 \pm 0.02$ & $0.09 \pm 0.01$ & $24.40 \pm 2.98$ & $12.66 \pm 1.41^{* *}$ & $0.63 \pm 0.06$ \\
\hline 2000MPK & $4.86 \pm 0.46$ & \multicolumn{2}{|c|}{$1.65 \pm 0.17$} & $0.07 \pm 0.02$ & $0.08 \pm 0.01$ & $25.75 \pm 2.82$ & $11.92 \pm 1.27^{* *}$ & $0.62 \pm 0.10$ \\
\hline
\end{tabular}

Values are presented as the means \pm standard deviations.

GOT; Glutamate oxaloacetate transaminase, GPT; Glutamate pyruvate transaminase, LDH; Lactate dehydrogenase, T.CHO; Total cholesterol, HDL; High density lipoprotein, LDL; Low density lipoprotein, TG; Triglyceride, GLU; Glucose, TP; Total protein, ALB; Albumin, T-BIL; Total bilirubin, DBIL; Direct bilirubin, BUN; Blood urea nitrogen, IP; Inorganic phosphorous, CREA; Creatinine.

${ }^{*} p<0.05$ : Significantly different from the naive by Dunnett's t-test.

$* * p<0.01$ : Significantly different from the naive by Dunnett's t-test.

Table 3 Absolute organ weights (g) of male Balb/c mouse treated with A. tsao-ko extract for 21 days

\begin{tabular}{|c|c|c|c|c|c|c|c|}
\hline \multirow{2}{*}{ Dose (mg/kg) } & \multirow{2}{*}{$\frac{\text { Sex }}{\text { organ }(g)}$} & \multicolumn{6}{|c|}{ Male } \\
\hline & & liver & lung & heart & kidney (L) & spleen & weight \\
\hline Naïve & & $1.272 \pm 0.027$ & $0.171 \pm 0.018$ & $0.124 \pm 0.007$ & $0.183 \pm 0.011$ & $0.101 \pm 0.008$ & $24.23 \pm 0.705$ \\
\hline Vehicle & & $1.246 \pm 0.036$ & $0.165 \pm 0.007$ & $0.119 \pm 0.009$ & $0.179 \pm 0.006$ & $0.096 \pm 0.007$ & $23.67 \pm 1.165$ \\
\hline 250 & & $1.267 \pm 0.065$ & $0.168 \pm 0.012$ & $0.121 \pm 0.006$ & $0.183 \pm 0.012$ & $0.102 \pm 0.007$ & $23.68 \pm 0.872$ \\
\hline 500 & & $1.277 \pm 0.076$ & $0.179 \pm 0.027$ & $0.127 \pm 0.005$ & $0.189 \pm 0.005$ & $0.103 \pm 0.008$ & $23.75 \pm 0.821$ \\
\hline 1000 & & $1.274 \pm 0.078$ & $0.169 \pm 0.008$ & $0.120 \pm 0.007$ & $0.179 \pm 0.010$ & $0.098 \pm 0.004$ & $23.94 \pm 0.836$ \\
\hline 2000 & & $1.282 \pm 0.071$ & $0.174 \pm 0.011$ & $0.120 \pm 0.008$ & $0.186 \pm 0.012$ & $0.104 \pm 0.012$ & $24.04 \pm 1.076$ \\
\hline
\end{tabular}

Values are presented as the means \pm standard deviations.

$(p<0.05)$

범위 내에서의 변화로써 최대무독성용량은 최고 투여량인 2000 $\mathrm{mg} / \mathrm{kg}$ 이상으로 판단되며, 이후에 추가적으로 13 주 반복 경구 투여 독성시험과 유전독성에 대한 연구들이 진행된다면, 앞으로 초과의 기능성 식품, 화장품, 의약품 등 다양한 소재로서의 활 용에 관심을 받게 될 것으로 생각된다. 본 연구 결과는 초과에 대한 과학적인 안전성 기초자료로 활용될 수 있을 것으로 사료 된다.

\section{초 록}

본 연구는 다양한 효능을 지닌 초과(Amomum tsao-ko Crevost et Lemaire)의 안전한 이용을 위한 독성평가로 식품의약품안전 처 고시 제2014-6호 ‘의약품등의 독성시험기준’에 맞는 독성시 험법에 따라 Balb/c mouse를 이용하여 3주간 반복경구투여를 통해 초과의 안전성을 확인하고자 하였다. 3 주간 반복 경구투
여 후 체중, 장기중량 측정, 혈액분석 및 혈액생화학 검사를 실 시하여 안전성을 확인 한 결과, 초과에 의한 특별한 증상이나 체중, 장기중량의 변화는 관찰되지 않았으며, 복대동맥으로부터 채혈한 혈액을 통한 혈구분석결과에서도 대조군과 초과 추출물 투여군 간의 통계적인 유의성을 관찰 할 수 없었다. 또한 혈청 을 이용하여 간기능(GOT, GPT, LDH, ALB, TP-S, T-BIL, D$\mathrm{BIL})$, 신장기능(BUN, $\mathrm{CRE})$, 지질영양 관련(TG), 전해질 관련 (I.P) 지표들의 생화학분석을 수행한 결과, 대조군과 유사하게 모두 정상 범위 내의 결과를 나타내었다. 이러한 결과를 통하 여 초과 추출물의 최대무독성용량은 최고 투여량인 $2000 \mathrm{mg} / \mathrm{kg}$ 이상으로 판단되며, 본 연구결과는 초과의 기능성 식품, 화장품, 의약품 등 다양한 소재로서의 활용에 안전성 관련 기초자료로 이용될 수 있을 것으로 사료된다.

Keywords 3주반복 경구독성 - 생화학분석 - 초과 - 혈구분석 - Balc/c 마우스 
감사의 글 본 연구는 산업통상자원부에서 시행한 “지역특화기술융복합연 구지원사업”(발효기술을 활용한 지리산권 천연소재의 항염증성 질환 예방 및 개선용 제품기술개발, R0002043)의 지원으로 이루어진 결과로 이에 감사드 립니다.

\section{References}

Chung TH, Shim KS, Kim DS, Lee JH, and Ma JY (2011) Single dose oral toxicity and genotoxicological safety study of Ssanghwa-tang fermented with Lactobacillus acidophyllus. J Korean Oriental Med 32, 67-83.

Hwang IY, Hwang SA, and Jeong CS (2013) Effects of Kalopanax pictus extracts and their related origin on gastric lesions. J Fd Hyg Safety 28, 367-75.

Kim YB, Hong DH, Cho ES, Lm WJ, Kim IH, and Son HY (2014) Effect of repeated Paecilomyces japonica treatment on rats. Korean J Vet Res 54, 31-8.

Lee JE, Kim HJ, Choi EK, Chai HY, Yun YW, Kim DJ et al. (2003) Fourweek repeated-dose toxicity study on Pinellia Extract. Korean J Lab Anim Sci 19, 127-41.

Lee JS, Lee JS, Park YC, Choi SM, and Lee SH (2014) A repeated-dose 28day oral toxicity test of Aconitum jaluense extract in sprague-dawley rats. Yakhak Hoeji 58, 62-70.

Li B, Choi HJ, Lee DS, Oh H, Kim YC, Moon JY et al. (2014) Amomum tsao-ko suppresses lipopolysaccharide-induced inflammatory responses in RAW264.7 macrophages via Nrf2-dependent heme oxygenase-1 expression. Am J Chin Med 42, 1229-44.

Moon SS, Cho SC, and Lee JY (2005) Tsaokoarylone, a cytotoxic diarylheptanoid from Amomum tsao-ko fruits. Bull Korean Chem Soc 26, 447-50.

Moon SS, Lee JY, and Cho SC (2004) Isotsaokoin, an antifungal agent from Amomum tsao-ko. J Nat Prod 67, 889-91.

Na CS, Hong CY, Na DS, Kim JB, Yoon SY, Lee SB et al. (2013) Hotwater extract of Hovenia dulcis peduncle improves exercise performance and anti-fatigue effect in Mice. Kor J Pharmacogn 44, 83-90.

Roh HS, Seok JH, Jeong JY, Lee JK, Kim TS, Choi HK et al. (2014) Repeated dose oral toxicity study of Alismatis rhizoma in SD Rats. $J$ Korean Med Ophthalmol Otolaryngol Dermatol 27, 79-90.

Um MY, Ha TY, Seong KS, and Kim YS (2013) In vitro screening of the acetylcholinesterase inhibition, anti-oxidant activity, and neuronal cell protective effect of medicinal plant extracts. Korean J Food Preserv 20, 840-5.

Yang Y, Yue Y, Runwei Y, and Guolin Z (2010) Cytotoxic, apoptotic and antioxidant activity of the essential oil of Amomum tsao-ko. Bioresour Technol 101, 4205-11.

Yoo JG and Jung JY (2012) Studies on the repeated toxicity test of food red No. 2 for 4 weeks oral administration in SD Rat. J Fd Hyg Safety 27, 429.

Yoon HJ, Choe MS, Cho HJ, Han BS, Park KH, Oh JA et al. (2014) Study of kidney toxicity of Azadirachta indica extract for oral administration in rats. Korean J Environ Agric 33, 103-10.

Yu L, Shirai N, Suzuki H, Sugane N, Hosono T, Nakajima Y et al. (2010) The effect of methanol extracts of tsao-ko (Amomum tsao-ko Crevost et Lemaire) on digestive enzyme and antioxidant activity in vitro, and plasma lipids and glucose and liver lipids in mice. J Nutr Sci Vitaminol (Tokyo) 56, 171-6. 